\title{
Regulation of Gonadotropin-Releasing Hormone Secretion by Kisspeptin/Dynorphin/Neurokinin B Neurons in the Arcuate Nucleus of the Mouse
}

\author{
Victor M. Navarro, ${ }^{1}$ Michelle L. Gottsch, ${ }^{2}$ Charles Chavkin, ${ }^{3}$ Hiroaki Okamura, ${ }^{4}$ Donald K. Clifton, ${ }^{2}$ and Robert A. Steiner ${ }^{1,2}$ \\ Departments of ${ }^{1}$ Physiology and Biophysics, ${ }^{2}$ Obstetrics and Gynecology, and ${ }^{3}$ Pharmacology, University of Washington, Seattle, Washington 98195 , \\ and ${ }^{4}$ Laboratory of Neurobiology, National Institute of Agrobiological Sciences, Tsukuba, Ibaraki 305-0901, Japan
}

\begin{abstract}
Kisspeptin is encoded by the Kiss 1 gene, and kisspeptin signaling plays a critical role in reproduction. In rodents, kisspeptin neurons in the arcuate nucleus (Arc) provide tonic drive to gonadotropin-releasing hormone ( $\mathrm{GnRH})$ neurons, which in turn supports basal luteinizing hormone (LH) secretion. Our objectives were to determine whether preprodynorphin (Dyn) and neurokinin $B(N K B)$ are coexpressed in Kiss 1 neurons in the mouse and to evaluate its physiological significance. Using in situ hybridization, we found that Kiss1 neurons in the Arc of female mice not only express the Dyn and NKB genes but also the NKB receptor gene (NK3) and the Dyn receptor [the $\kappa$ opioid receptor $(K O R)$ ] gene. We also found that expression of the $D y n, N K B, K O R$, and $N K 3$ in the Arc are inhibited by estradiol, as has been established for Kiss1, and confirmed that Dyn and NKB inhibit LH secretion. Moreover, using Dyn and KOR knock-out mice, we found that long-term disruption of $D y n / K O R$ signaling compromises the rise of LH after ovariectomy. We propose a model whereby NKB and dynorphin act autosynaptically on kisspeptin neurons in the Arc to synchronize and shape the pulsatile secretion of kisspeptin and drive the release of GnRH from fibers in the median eminence.
\end{abstract}

\section{Introduction}

Kisspeptin signaling plays a critical role in the neuroendocrine regulation of reproduction (Popa et al., 2008). Kisspeptin activates gonadotropin-releasing hormone $(\mathrm{GnRH})$ neurons (Gottsch et al., 2004; Han et al., 2005), which are the final common pathway by which the brain regulates the gonadotropin secretion, and pulsatile secretion of kisspeptin and $\mathrm{GnRH}$ are temporally linked (Keen et al., 2008). The Kiss1 gene encodes kisspeptin, which is expressed by neurons in the arcuate nucleus (Arc) of the hypothalamus (Smith et al., 2005a,b), the nodal point for controlling the negative feedback regulation of $\mathrm{GnRH}$ secretion by estradiol $\left(\mathrm{E}_{2}\right)$ and for generating pulsatile GnRH secretion (Freeman, 2005). Kiss 1 neurons in the Arc express estrogen receptor- $\alpha(\mathrm{ER} \alpha)$ (Smith et al., 2005b), which mediates negative feedback and the inhibition of Kiss 1 expression in the Arc (Smith et al., 2005b; Glidewell-Kenney et al., 2007). Thus, Kiss1 neurons in the Arc may be conduits for receiv-

Received April 1, 2009; revised June 6, 2009; accepted July 30, 2009.

This research was supported by the Eunice Kennedy Shriver National Institute of Child Health and Human Development/National Institutes of Health (NICHD/NIH) through Cooperative Agreement U54 HD12629 (to the University of Washington Center for Research in Reproduction and Contraception), NICHD/NIH Grant R01 HD27142, National Institute on Drug Abuse/NIH Grants R01 DA016898 and K05 DA020570, the Fulbright/MEC Program of the United States Department of State and Ministerio Español de Ciencia e Innovación, the Marie Curie Outgoing International Fellowship supported by the 7th Frame Programme of the European Union, and the Program for Promotion of Basic Research Activities for Innovative Bioscience (PROBRAIN) of Japan. We are grateful for the technical assistance provided by Sarah McConkey, Sarah Ahmad, and Dan Messinger at the University of Washington (Seattle, WA) and Brigitte Mann at Northwestern University (Evanston, IL). We thank Drs. Martin Kelly and Oline Ronnekleiv at the Oregon Health and Science University (Portland, OR) for their constructive comments on a previous draft of this manuscript.

Correspondence should be addressed to Robert A. Steiner, University of Washington, Department of Physiology and Biophysics, Box 357290, Seattle, WA 98195-7290. E-mail: steiner@u.washington.edu.

D0I:10.1523/JNEUROSCI.1569-09.2009

Copyright $\odot 2009$ Society for Neuroscience $\quad 0270-6474 / 09 / 2911859-08 \$ 15.00 / 0$ ing $\mathrm{E}_{2}$ signaling from the gonad and relaying that information to GnRH neurons (Smith et al., 2005b). However, Kiss 1 neurons in the Arc also express several cotransmitters, which may have important, independent functions.

In the sheep, Kiss 1 neurons in the Arc coexpress dynorphin A (Dyn) and neurokinin B (NKB) (Goodman et al., 2007), and both Dyn and NKB have been implicated in the regulation of luteinizing hormone (LH) secretion. Dyn, which acts via the $\kappa$ opioid receptor (KOR) (Chavkin et al., 1982), inhibits LH release (Schulz et al., 1981; Kinoshita et al., 1982), as does NKB (Sandoval-Guzmán and Rance, 2004). Moreover, disabling mutations of either NKB (known as TAC3 in humans) or the NKB type 3 receptor gene (NK3) (known as TAC3R in humans) are associated with reproductive failure (Topaloglu et al., 2009). Thus, three neuropeptides are produced by a single population of cells in the Arc (in the sheep), and all three have been independently linked to GnRH secretion. However, the nature of the interaction among these cotransmitters and their physiological significance remains a mystery. We postulated that kisspeptin, Dyn, and NKB work together to generate episodic kisspeptin secretion, which drives the pulsatile secretion of $\mathrm{GnRH}$, based on several lines of reasoning. First, in the rat, Dyn/NKB-containing fibers contact Dyn/NKB-containing soma in the Arc (Burke et al., 2006), suggesting that recurrent collaterals shape and synchronize periodic firing of Kiss1/Dyn/NKB neurons. Second, Dyn/ NKB-containing fibers project from the Arc and terminate near $\mathrm{GnRH}$ fibers or terminals in the median eminence (ME) (Burke et al., 2006). Finally, GnRH neurons express both the kisspeptin receptor (Kiss1r) and NK3 (Irwig et al., 2004; Krajewski et al., 2005). The studies described here were designed to test this 
model. First, we evaluated whether Dyn and NKB are coexpressed in Kiss 1 neurons in the Arc of the mouse. Second, we determined whether Kiss1 neurons express KOR and NK3. Third, we tested whether Dyn and $N K B$ are targets for regulation by $\mathrm{E}_{2}$, and fourth, we studied the effects of KOR and NK3 agonists and the impact of genetically targeted deletions of Dyn and KOR on $\mathrm{GnRH} / \mathrm{LH}$ secretion.

\section{Materials and Methods}

Animals

Animals were housed at the University of Washington, and all procedures and surgeries were approved by the Animal Care Committee of the University of Washington School of Medicine in accordance with the National Institutes of Health Guide for the Care and Use of Laboratory Animals.

Adult female C57BL/6 mice (8 weeks old) were purchased from The Jackson Laboratory. C57BL/6 mice with a prodynorphin (Dyn) gene deletion were generated as described previously (McLaughlin et al., 2003), and homozygous $(-/-)$ and paired wild-type $(+/+)$ littermate controls were generated by heterozygote crosses. Homozygous KOR gene deletion $(-/-)$ mice (C57BL/6 background) were prepared by homologous recombination as described previously (Clarke et al., 2002) and provided for this study. Female ER $\alpha$ null mice (C57BL/6 background) were produced by breeding heterozygote pairs, each carrying a single copy of the disrupted $E R \alpha$ gene, as described previously (Lubahn et al., 1993; Smith et al., 2005b). Animals were housed in groups of three to five, maintained on a 14/10 light cycle with lights on at 4:00 A.M. and had access to standard rodent chow and water ad libitum.

\section{Ovariectomy and steroid replacement}

Ovariectomy (OVX) was performed on adult female mice through bilateral lumbar incisions, while maintaining the animals under isoflurane inhalation anesthesia (Abbott Laboratory) delivered by a vaporizer (Veterinary Anesthesia Systems). Vasculature to the ovary was sutured, and wound clips were used to close the incision. Immediately after OVX, oil-filled capsules (sham) or $\mathrm{E}_{2}$ plus oil-filled capsules were implanted subcutaneously via a small midscapular incision at the base of the neck; wound clips were used to close the incision. For $\mathrm{E}_{2}$ implants, SILASTIC tubing (inner diameter, $1.47 \mathrm{~mm}$; outer diameter, $1.95 \mathrm{~mm}$; Dow Corning) was cut to $9 \mathrm{~mm}$; one end was sealed with silicone cement and allowed to cure overnight. Crystalline $\mathrm{E}_{2}$ (Sigma) at a dose of $1 \mathrm{mg} / \mathrm{ml}$ was dissolved in safflower oil based on previous studies (Miller et al., 1995; Smith et al., 2005b; Dungan et al., 2007). After capsules were filled with $E_{2}$ in oil, the end of the capsule was sealed with silicone cement and allowed to cure overnight. The day before surgery, implants were washed two times for $10 \mathrm{~min}$ in changes of $100 \%$ ethanol and then placed in sterile physiological saline overnight.

\section{Tissue preparation}

Blood was centrifuged for $5 \mathrm{~min}$ (3000 rpm), and the serum was stored at $-20^{\circ} \mathrm{C}$ until hormone measurements. Brains were removed for in situ hybridization (ISH), frozen on dry ice, and then stored at $-80^{\circ} \mathrm{C}$ until sectioned. Five sets of $20 \mu \mathrm{m}$ sections in the coronal plane were cut on a cryostat (from the diagonal band of Broca to the mammillary bodies), thaw mounted onto SuperFrost Plus slides (VWR Scientific), and stored at $-80^{\circ} \mathrm{C}$. A single set was used for in situ hybridization (adjacent sections $100 \mu \mathrm{m}$ apart).

\section{Radioimmunoassays}

Serum levels of LH were measured at Northwestern University (Evanston, IL). Reagents for the LH assay were obtained from NIH. For LH, the antiserum used was anti-rLH-S-11, and the standard was rLH-RP3. The assay sensitivity was $0.2 \mathrm{ng} / \mathrm{ml}$, and the intra-assay coefficient of variation was $4 \%$.

\section{Detection of Kiss 1 mRNA}

The Kiss 1 probe used for detection of Kiss 1 mRNA was described previously (Gottsch et al., 2004). The Kiss1-specific sequence of the probe spans bases 76-486 of the mouse cDNA sequence (GenBank accession number AF472576). The procedure for ISH is outlined below.

\section{Detection of Dyn $m R N A$}

The Dyn probe used for detection of Dyn mRNA was described previously (Gottsch et al., 2009). The Dyn-specific sequence of the probe spans bases 132-540 of the mouse cDNA sequence (GenBank accession number NM_018863). The procedure for in situ hybridization is outlined below.

\section{Detection of KOR, NKB, and NK3 $m R N A s$}

Total RNA was extracted from mouse brain using an RNAqueous kit (Ambion). RNA was reverse transcribed into cDNA with a RetroScript kit (Ambion) primed with oligodeoxythymidine for subsequent PCR. Primers were designed based on the published sequence of the KOR mouse gene (GenBank accession number NM_011011) with forward primers starting at $127 \mathrm{bp}$ and reverse primers starting at $964 \mathrm{bp}, N K B$ mouse gene (GenBank accession number NM_009312) with forward primers starting at $177 \mathrm{bp}$ and reverse primers starting at $440 \mathrm{bp}$, and NK3 mouse gene (GenBank accession number NM_021382) with forward primers starting at $286 \mathrm{bp}$ and reverse primers starting at $691 \mathrm{bp}$. Primers were custom synthesized (OPERON). PCR reactions contained the following in a volume of $25 \mu \mathrm{l}: 2 \mu \mathrm{l}$ of reverse transcriptase reaction product, $0.2 \mu \mathrm{M}$ of each primer, $12.5 \mu \mathrm{l}$ of RediTaq polymerase (SigmaAldrich), and $8.5 \mu \mathrm{l}$ of water. Reactions were performed in a PTC-100 thermal cycler (MJ Research) using the following protocol: cDNA was denatured for $5 \mathrm{~min}$ at $94^{\circ} \mathrm{C}$, and then 35 cycles were performed at $94^{\circ} \mathrm{C}$ for $1 \mathrm{~min}, 55^{\circ} \mathrm{C}$ for $1.5 \mathrm{~min}$, and $72^{\circ} \mathrm{C}$ for $2 \mathrm{~min}$, with a final $5 \mathrm{~min}$ extension at $72^{\circ} \mathrm{C}$. After electrophoresis on a $2 \%$ agarose $(\mathrm{w} / \mathrm{v})$ gel, a single DNA fragment was obtained of approximately the expected size and gel purified with a QiaQuick gel extraction kit (Qiagen). The PCR product was confirmed to be the mouse $K O R, N K B$, or $N K 3$ probe by sequencing. Clamp polymerase sequences for $\mathrm{T} 7$ or $\mathrm{T} 3$ polymerase were added for the final primer product sequence and transcribed for ISH.

\section{Single-label in situ hybridization of Dyn $m R N A$}

Dyn mRNA sense and antisense probes were transcribed with T7 or T3 polymerase (Fermentas) as described previously by Gottsch et al. (2009). Briefly, radiolabeled probes were synthesized in vitro by inclusion of the following ingredients in a volume of $20 \mu \mathrm{l}: 250 \mu \mathrm{Ci}\left[{ }^{33} \mathrm{P}\right] \mathrm{UTP}$ (PerkinElmer Life and Analytical Sciences), $1 \mu \mathrm{g}$ of linearized DNA (or 1 $\mu \mathrm{g}$ of PCR product), $0.5 \mathrm{~mm}$ each ATP, CTP, and GTP, and $40 \mathrm{U}$ of polymerase. Residual DNA was digested with $4 \mathrm{U}$ of DNase (Ambion), and the DNase reaction was terminated by addition of $2 \mu \mathrm{l}$ of $0.5 \mathrm{M}$ EDTA, pH 8.0. The riboprobes were separated from unincorporated nucleotides with NucAway Spin Columns (Ambion).

Slides with mouse hypothalamic sections from the different experimental groups were processed as reported previously (Cunningham et al., 2002; Gottsch et al., 2004).

\section{Double-label in situ hybridization}

Antisense mouse Kiss 1 probe was transcribed from linearized pAMP1 plasmid containing the mouse Kiss 1 insert with T7 polymerase (Fermentas) (Gottsch et al., 2004). The cDNA template for the Dyn, KOR, NKB, and NK3 riboprobes were generated by PCR with primers that were designed to contain promoters for T7 RNA polymerase in the antisense direction and T3 RNA polymerase in the sense direction. Radiolabeled riboprobes for $K O R, N K B$, and $N K 3$ were synthesized as described above for the Dyn riboprobe. Digoxigenin (DIG)-labeled Kiss1 antisense riboprobe was synthesized with T7 RNA polymerase and DIG labeling mix (Roche) according to the instructions of the manufacturer. Slides were processed for double-labeled in situ hybridization as described previously (Irwig et al., 2004). Slides were stored at $4^{\circ} \mathrm{C}$ and developed $8-12 \mathrm{~d}$ later.

\section{Quantification and analysis of Kiss1, Dyn, KOR, NKB,} and NK3 mRNAs

The brain sections were analyzed bilaterally unless otherwise specified. Slides from all of the animals were assigned a random three-letter code, alphabetized, and read under dark-field illumination with custom- 
designed software designed to count the total number of cells and the number of silver grains (corresponding to radiolabeled Dyn, KOR, $N K B$, or NK3 mRNA) over each cell (Chowen et al., 1990). Kiss1 mRNAcontaining cells were visualized under fluorescent illumination, and custom-designed software was used to count the number of silver grains over each Kiss 1 cell depending on which radiolabeled probe was used. The number of cells reported for each experiment represents the number of cells within the coronal sections containing the Arc nucleus for each set, not the total number of cells in the Arc. The starting and ending point of quantification was determined according to Paxinos and Franklin (2001). Signal-to-background ratios (SBRs) for individual cells were calculated; an individual cell was considered to be double labeled if it had an SBR of three or more. For each animal, the number of doublelabeled cells was calculated as a percentage of the total number of Kiss 1 mRNA-positive cells and then averaged across animals to produce a mean \pm SEM.

\section{Statistical analysis}

All data are expressed as the mean \pm SEM for each group. One-way ANOVA was used to assess variation among experimental groups in each experiment. Significance level was set at $p<0.05$. All analyses were performed with Statview 5.0.1 for Macintosh (SAS Institute).

\section{Experimental design}

Experiment 1: coexpression of Kiss1/Dyn mRNAs in the forebrain. The purpose of this experiment was to determine whether Kiss 1 neurons in the mouse female forebrain [Arc and anteroventral periventricular nucleus (AVPV)] coexpress Dyn mRNA. Wild-type (WT) mice were divided into two groups ( $n=5$ per group): OVX + sham and OVX $+\mathrm{E}_{2}$ replacement. At approximately 9:00 A.M. on $7 \mathrm{~d}$ after castration, mice were anesthetized with isoflurane, blood was collected for $\mathrm{LH}$ radioimmunoassays by retro-orbital bleeding to confirm gonadectomy, and mice were killed by decapitation. Brains were collected as described above.

Experiment 2: regulation of Dyn $m R N A$ by $E_{2}$. The purpose of this experiment was to analyze the regulation of Dyn mRNA by $\mathrm{E}_{2}$ and determine whether $\mathrm{E}_{2}$ can regulate this expression in $E R \alpha$ knock-out (KO) female mice. Seven female $E R \alpha \mathrm{KO}$ mice and seven WT littermates were ovariectomized, and four from each group received $\mathrm{E}_{2}$ replacement. Tissue collection and preparation for Dyn mRNA in situ hybridization was performed as described in experiment 1.

Experiment 3: coexpression of Kiss1/KOR mRNAs in the Arc. The purpose of this experiment was to determine whether Kiss 1 and KOR are coexpressed in cells in the Arc and to assess the possible regulation of KOR mRNA by $\mathrm{E}_{2}$. We performed double-labeled in situ hybridization on a set of coronal sections from brains of OVX + sham and OVX $+\mathrm{E}_{2}$ adult female mice ( $n=8$ per group), generated as described above. Kiss 1 mRNA was visualized via DIG-labeled riboprobes.

Experiment 4: coexpression of Kiss1/NKB/NK3 mRNAs in the AVPV and the Arc. The purpose of this experiment was to determine whether Kiss1, NKB, and NK3 are coexpressed in cells in the Arc (as well as the AVPV for Kiss 1/NKB) and to assess their possible regulation by $\mathrm{E}_{2}$. We performed double-labeled in situ hybridization on a set of coronal sections from brains used in the previous experiment (OVX + sham and $\mathrm{OVX}+\mathrm{E}_{2}$ mice; $n=8$ per group). Kiss $1 \mathrm{mRNA}$ was visualized by the use of DIG-labeled riboprobes.

Experiment 5: postcastration LH response in adult female Dyn KO and KOR KO mice. The purpose of this experiment was to determine the effect of long-term deficiency of either Dyn or KOR in controlling the $\mathrm{GnRH} / \mathrm{LH}$ response to reduced circulating levels of $\mathrm{E}_{2}$. Ten adult female $D y n$ KO mice, 8 adult female KOR KO mice, and 10 adult WT littermates (between 8 and 12 weeks of age) were ovariectomized, and blood was collected after $7 \mathrm{~d}$ as described in experiment 1 (for LH determinations). This experiment showed a reduced rise in serum levels of LH after OVX in Dyn KO and KOR KOs compared with their respective WT controls. To investigate whether this phenomenon might be attributable to a decrease in kisspeptin drive to GnRH neurons, WT and Dyn KO animals (five adult female mice for each group) were subjected to the same protocol described above. At 1 week after OVX, brain levels of Kiss1 mRNA were measured and compared between genotypes by quantitative ISH (after confirming that the postcastration rise in $\mathrm{LH}$ was compromised in the Dyn KOs).

Experiment 6: response of LH serum levels to U50488. The purpose of this experiment was to assess the effect of the KOR agonist U50488 [(trans)-3,4-dichloro- $N$-methyl- $N$-[2-1-pyrrolidinyl)-cyclo-hexyl] benzeneacetamide] (Tocris Biosciences) on serum LH levels in adult ( 8 weeks old) female WT mice, in the presence and absence of $E_{2}$. Animals were ovariectomized as described above ( $n=10$ per group) and allowed to recover for $7 \mathrm{~d}$. Each group received an intraperitoneal injection of vehicle $(0.9 \% \mathrm{NaCl})$ or U50488 $\left(5 \mathrm{mg} \cdot \mathrm{kg}^{-1} \cdot \mathrm{ml}^{-1}\right)$. After $30 \mathrm{~min}$, animals were bled and serum was collected as described in experiment 1 . In addition, adult WT OVX mice were implanted with $\mathrm{E}_{2}$-containing capsules and treated intraperitoneally with vehicle or U50488 ( $n=10$ per group) following the same protocol.

Experiment 7: $\mathrm{LH}$ response to NK3 agonist. The purpose of this experiment was to assess the effect of the NK3 agonist senktide (Sigma-Aldrich) on LH secretion in adult ( 8 weeks old) female WT mice, in the presence and absence of $E_{2}$. Animals were ovariectomized and implanted with empty capsules $(\mathrm{OVX}+$ sham $)$ or $\mathrm{E}_{2}$ capsules $\left(\mathrm{OVX}+\mathrm{E}_{2}\right)$ as described above ( $n=7-10$ per group). Each group was equally divided and received an intracerebroventricular injection (Gottsch et al., 2004) of vehicle $(0.9 \% \mathrm{NaCl})$ or senktide $(600 \mathrm{pmol} / 3 \mu \mathrm{l})$ as described previously (Sandoval-Guzmán and Rance, 2004). After $30 \mathrm{~min}$, the animals were bled and serum was collected as described in experiment 1 .

\section{Results \\ Coexpression of Kiss1/Dyn genes and the regulation of Dyn gene by $\mathrm{E}_{2}$}

The percentage of Kiss1 neurons expressing Dyn in OVX mice with and without $\mathrm{E}_{2}$ treatment was assessed by double-labeled ISH. In the Arc, nearly all (92\%) of the Kiss1 neurons coexpressed Dyn (Fig. 1A). Dyn was also found in some Kiss1-containing cells in the AVPV, but the extent of coexpression was only $33 \%$. Levels of Dyn mRNA in Kiss1 cells of the AVPV—as indicated by the number of silver grains per cell-was low, amounting to $<10 \%$ of that found in Kiss 1 cells of the Arc (OVX + sham AVPV, <2 gpc; OVX + $\mathrm{E}_{2}$ AVPV, <2 gpc; OVX + sham Arc, $15 \pm 2$ gpc; OVX $+\mathrm{E}_{2}$ Arc, $17 \pm 2$ gpc). $\mathrm{E}_{2}$ treatment did not affect the percentage of Dyn coexpressing Kiss1 cells in either the Arc or AVPV.

Single-labeled ISH was used to evaluate the ability of $\mathrm{E}_{2}$ to regulate Dyn expression in adult WT and ER $\alpha \mathrm{KO}$ mice. As shown in Figure $1 B$, the number of Dyn mRNA-containing cells in the Arc was high in OVX WT mice $(574 \pm 27)$, and $E_{2}$ treatment reduced the number of cells by $\sim 80 \%(112 \pm 21 ; p<0.01)$. $\mathrm{E}_{2}$ also reduced the per cell content of Dyn mRNA in the Arc (OVX + sham, $125 \pm 4$ gpc vs OVX $+\mathrm{E}_{2}, 44 \pm 4$ gpc; $p<0.01$ ). Dyn expression in the Arc of ER $\alpha \mathrm{KO}$ mice was unaffected by $\mathrm{E}_{2}$ treatment (Fig. $1 B)$, both in terms of cell numbers $(E R \alpha$ KO OVX + sham, $365 \pm 62$ cells vs ER $\alpha$ KO OVX $+E_{2}, 330 \pm 122$ cells; $p=$ $0.17)$ and gpc $(E R \alpha$ KO OVX + sham, $181 \pm 13$ gpc vs $E R \alpha$ KO OVX $+\mathrm{E}_{2}, 133 \pm 22$ gpc; $\left.p=0.66\right)$.

\section{Coexpression of Kiss1/KOR genes and regulation of $K O R$ by $\mathrm{E}_{2}$}

The coexpression of KOR mRNA in Kiss1 neurons of OVX mice with and without $\mathrm{E}_{2}$ was also determined by double-labeled ISH. KOR mRNA was found in $\sim 20 \%$ of the Kiss1 neurons in the Arc, regardless of $\mathrm{E}_{2}$ treatment. Although this would seem to be a relatively small fraction of the total number of Kiss 1 cells, it is significant and may reflect the relatively weak limits of detectability of the KOR riboprobe. Using the single-labeled approach, we found that $\mathrm{E}_{2}$ inhibited the expression of $K O R$ in cells inside the Arc, presumably including some that do not contain Kiss 1 (OVX + sham, $57 \pm 11$ cells vs OVX $+E_{2}, 19 \pm 4$ cells; $p<0.02$ ) (Fig. 
2). There were several hypothalamic areas that showed a greater expression of $K O R$ than the Arc, including the ventromedial nucleus, dorsomedial nucleus, and the caudal part of the periventricular nucleus (data not shown).

\section{Coexpression of Kiss1, NKB, and NK3} genes and regulation by $\mathrm{E}_{2}$ In the Arc, double-labeled ISH revealed that $\sim 90 \%$ of the Kiss1 neurons of OVX mice also expressed $N K B$ mRNA (regardless of $\mathrm{E}_{2}$ treatment) (Fig. $3 A$ ). Some cells in the Arc that contained NKB did not colabel with Kiss1 (data not shown). Only $\sim 10 \%$ of the Kiss 1 neurons in the AVPV coexpressed $N K B$, and the level of $N K B$ expression in those cells was much less than in the Arc (OVX + sham AVPV, $<1$ gpc; OVX $+\mathrm{E}_{2}$ AVPV, $<1$ gpc; OVX + sham Arc, $28 \pm 5$ gpc; OVX $+\mathrm{E}_{2}$ Arc, $30 \pm 35 \mathrm{gpc}$ ). It has been reported previously that $N K B$ in the Arc is regulated by $\mathrm{E}_{2}$ (Danzer et al., 1999; Goubillon et al., 2000; Pillon et al., 2003; Dellovade and Merchenthaler, 2004). In the present work, we studied the effect of $\mathrm{E}_{2}$ specifically in Kiss $1 / \mathrm{NKB}$ colabeled neurons. We found that $\mathrm{E}_{2}$ replacement decreased the population of these neurons in the Arc of OVX animals by 53\% when compared with the OVX + sham group (OVX + sham, $308 \pm 57$ vs $145 \pm 18$ cells; $p=0.027$ ) (Fig. 3C).

We also found that virtually all (96\%) of the Kiss1 neurons in the Arc of OVX mice coexpressed high levels of NK3 mRNA in the absence of $\mathrm{E}_{2}$ (Fig. 3B). Within the Arc, NK3 appeared to be expressed exclusively in Kiss1 neurons (data not shown). In the presence of $\mathrm{E}_{2}$, there were too few detectable Kiss1-expressing cells to determine the degree of $N K 3$ mRNA coexpression. In any case, there were no visible clusters of silver grains in the Arc of $E_{2}$-treated animals, suggesting that NK3 mRNA was profoundly suppressed by $\mathrm{E}_{2}$, as was the case for Kiss 1 mRNA in this region.

\section{Effect of a long-term deficit of $D y n / K O R$ signaling on the $\mathrm{LH}$ response to $\mathrm{OVX}$}

Serum LH levels in adult WT, Dyn KO, and KOR KO female mice were elevated $7 \mathrm{~d}$ after OVX compared with those in diestrus animals. However, the post-OVX LH levels observed in both Dyn $\mathrm{KO}$ and KOR KO mice were only 37 and $51 \%$ of the LH level in the WT group (WT, $1.95 \pm 0.3 \mathrm{ng} / \mathrm{ml}$; Dyn KO, $0.73 \pm 0.09$ $\mathrm{ng} / \mathrm{ml} ; p<0.01 ;$ KOR KO, $1.0 \pm 0.3 \mathrm{ng} / \mathrm{ml} ; p<0.05$ ) (Fig. 4). In OVX mice treated with $\mathrm{E}_{2}$, LH levels were not significantly different between WT and Dyn KO (WT, $0.202 \pm 0.001 \mathrm{ng} / \mathrm{ml}$ vs Dyn $\mathrm{KO}, 0.27 \pm 0.04 \mathrm{ng} / \mathrm{ml} ; p=0.29)$.

To determine whether reduced expression of Kiss1 in Dyn KOs might account for their reduced LH response to OVX, we compared levels of Kiss 1 mRNA between WT and Dyn KOs, following the same protocol used to assess serum LH levels. We confirmed that, $7 \mathrm{~d}$ after OVX, Dyn KOs had reduced LH levels compared with WTs (WT, $1.93 \pm 0.34 \mathrm{ng} / \mathrm{ml}$ vs Dyn KO, $0.92 \pm$ $0.26 \mathrm{ng} / \mathrm{ml} ; p<0.05)$. Furthermore, we found no significant

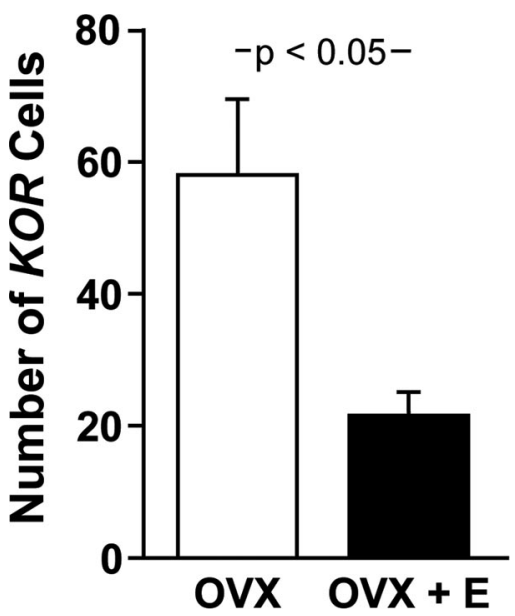

Figure 2. Effect of $E_{2}$ replacement on the number of $K O R$-expressing cells in coronal sections of the Arc in OVX WT mice. Data are presented as the mean \pm SEM.

difference in Kiss 1 mRNA between genotypes (WT, $59.2 \pm 18.17$ cells vs Dyn KO, $65.0 \pm 15.93$ cells; $p=0.81$ ).

\section{Action of KOR and NK3 agonists on $\mathrm{LH}$ secretion}

Although it has been shown in rats that KOR and NK3 agonists inhibit LH release, this has not been demonstrated in the mouse. In OVX (7 d) female mice, we found that administration of either the KOR agonist U50488 or the NK3 agonist senktide reduced serum LH levels after $30 \mathrm{~min}$ (vehicle + OVX, $1.92 \pm 0.27 \mathrm{ng} / \mathrm{ml}$ vs U50488 + OVX, $0.88 \pm 0.29 \mathrm{ng} / \mathrm{ml} ; p<0.01$; vehicle + OVX, $1.60 \pm 0.53 \mathrm{ng} / \mathrm{ml}$ vs senktide + OVX, $0.81 \pm 0.17 \mathrm{ng} / \mathrm{ml} ; p<$ 0.01 ) (Fig. 5). When this study was repeated in $\mathrm{E}_{2}$-treated OVX mice, serum levels of LH were exceedingly low (at or near the 

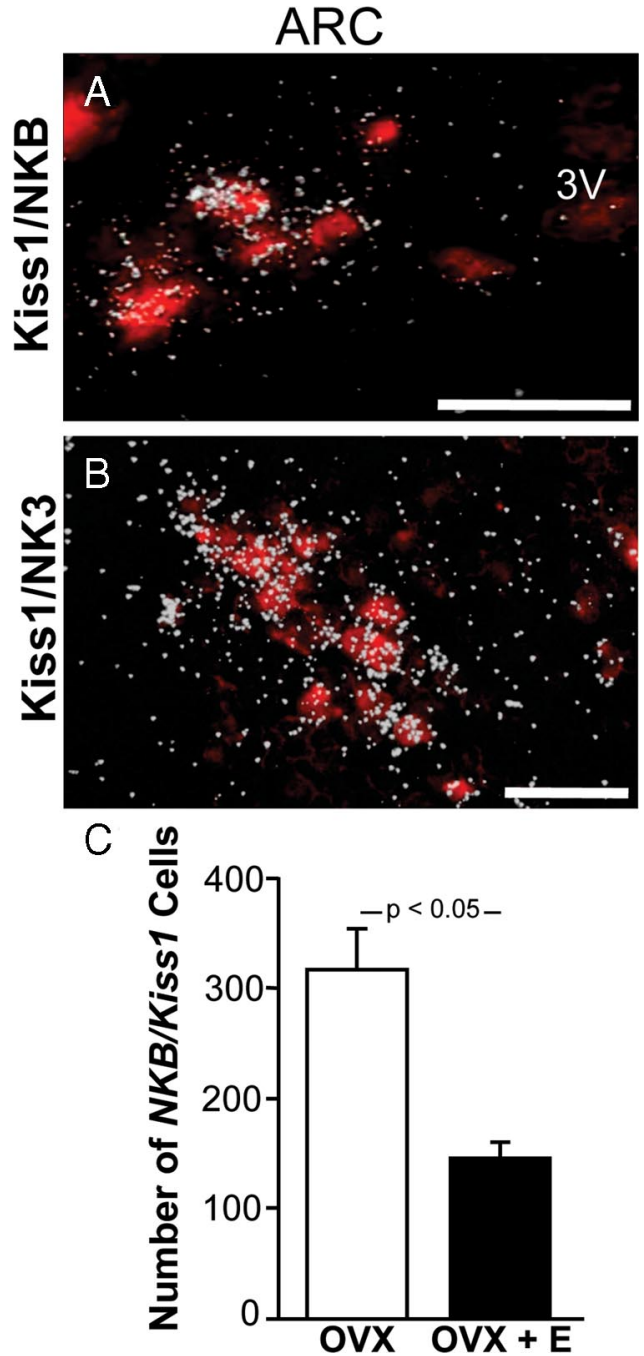

Figure 3. Representative photomicrographs showing coexpression of Kiss 1 mRNA with NKB $(\boldsymbol{A})$ and NK3 $(\boldsymbol{B})$ in the Arc of the female mouse. Kiss $1 \mathrm{mRNA}$-expressing cells are fluorescent with Vector Red substrate, and clusters of silver grains reflect the presence of NKB mRNA $(\boldsymbol{A})$ or NK3 mRNA $(\boldsymbol{B})$. Scale bars, $50 \mu \mathrm{m}$. Effect of $\mathrm{E}_{2}$ replacement on the number of Kiss $1 / N K B$ cells in coronal sections of the Arc in OVX WT mice. Data are presented as the mean \pm SEM (C).

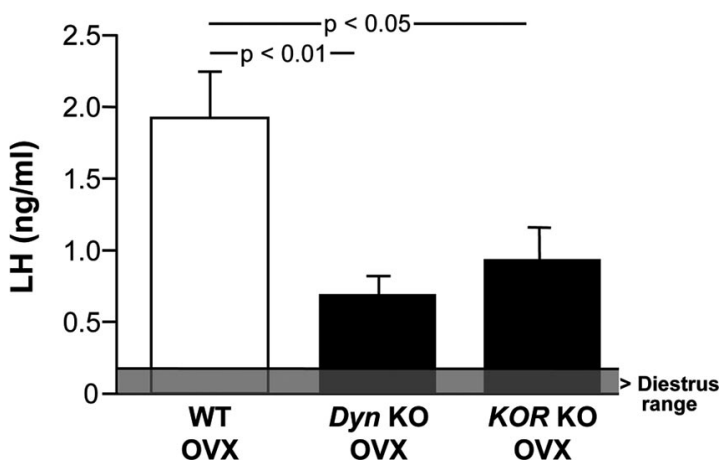

Figure 4. Serum LH levels in adult female WT, Dyn KO, and KOR KO mice $7 \mathrm{~d}$ after OVX compared with diestrus LH levels. Data are presented as the mean \pm SEM.

minimum detectable limits of the assay) and were indistinguishable among groups, regardless of treatment (vehicle + OVX + $\mathrm{E}_{2}, 0.28 \pm 0.09 \mathrm{ng} / \mathrm{ml}$ vs $\mathrm{U} 50488+\mathrm{OVX}+\mathrm{E}_{2}, 0.24 \pm 0.03 \mathrm{ng} / \mathrm{ml} ;$ senktide + OVX $+E_{2}, 0.20 \pm 0.0 \mathrm{ng} / \mathrm{ml}$ ) (Fig. 5).
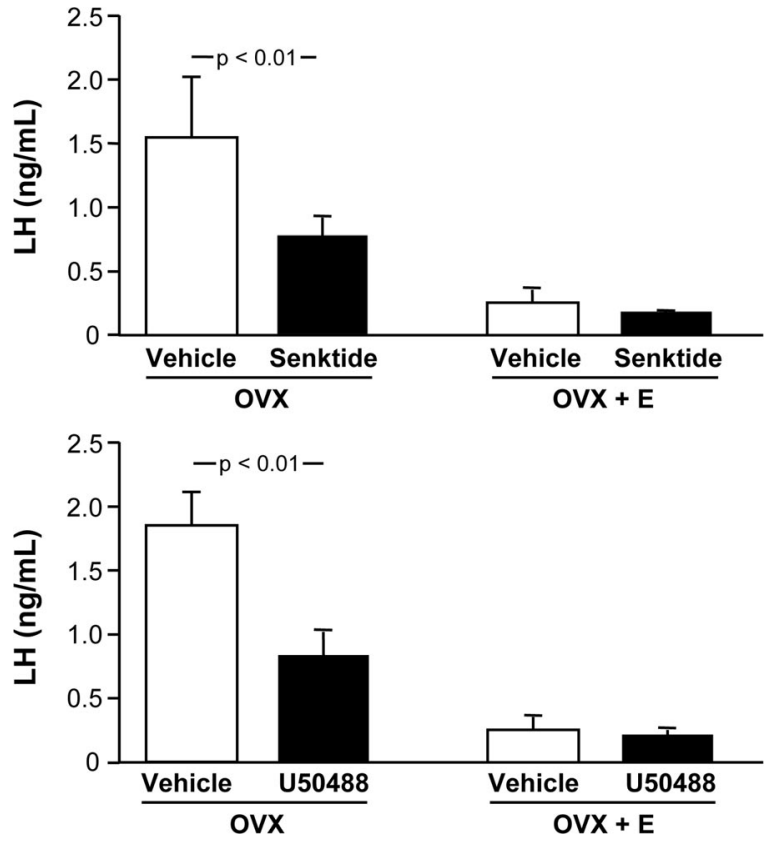

Figure 5. Serum LH levels in female WT mice (OVX + sham and $\left.O V X+E_{2}\right) 30$ min after treatment with vehicle or senktide (top), and vehicle or U50488 (bottom). Data are presented as the mean \pm SEM.

\section{Discussion}

Based on evidence from this and previous studies, we have proposed that Kiss1 neurons in the Arc of the mouse participate in the generation and regulation of pulsatile kisspeptin release that drives ultradian GnRH release (Fig. 6). Central to this model is the coexpression of Dyn and NKB in Kiss1 neurons of the Arc, which has been reported previously to occur in sheep (Goodman et al., 2007). Here, we show that this is also the case in the mouse, suggesting that the presence of Kiss1/Dyn/NKB neurons of the Arc may be common across diverse species. Furthermore, because we found that most of the cells containing Dyn and/or NKB in the Arc are Kiss1 neurons, we can reasonably infer that previous descriptions of the distribution of kisspeptin-, Dyn-, and NKB-containing fibers in the Arc also describe the distribution of fibers from Kiss1/Dyn/NKB neurons, which should contain all three neuropeptides. Using immunohistochemistry coupled with confocal microscopy, Burke et al. (2006) found that a plexus of axons and terminals containing Dyn and NKB surround and abut Dyn/NKB cell bodies in the Arc of the rat. These observations suggest that Kiss1/Dyn/NKB neurons are interconnected via recurrent collaterals, as shown in Figure 6. In addition, Dyn/NKB fibers project from the Arc to the ME in the rat, sheep, and horse (Burke et al., 2006; Foradori et al., 2006; Decourt et al., 2008), and in the monkey kisspeptin fibers have been shown to have extensive and intimate associations with $\mathrm{GnRH}$ axons in the ME (Ramaswamy et al., 2008). Thus, we deduce that axons from Kiss1/Dyn/NKB soma in the Arc of the mouse project to one another and to the ME in the vicinity of $\mathrm{GnRH}$ fibers and terminals.

Presumably, kisspeptin, Dyn, and NKB are all available to act as cotransmitters or neuromodulators at the targets of projections from Kiss1/Dyn/NKB soma in the Arc, and any specific action would occur as a function of the presence (or absence) of Kiss1r, $\mathrm{KOR}$, and NK3 in those potential targets. Remarkably, the targets of the recurrent collaterals appear to be Kiss1/Dyn/NKB cells themselves. Dyn cells in the Arc express NK3 (Burke et al., 2006), 
and our results confirm that Kiss1expressing cells coexpress $N K 3$, implying that the recurrent collaterals could signal through an NKB/NK3 signaling pathway. In addition, $K O R$ is expressed in Kiss 1 neurons (albeit at low levels), so it is plausible that Dyn/KOR signaling is also involved in communication through these same recurrent collaterals (or conceivably through interneurons). Kiss1r mRNA does not appear to be expressed in the Arc (d'Anglemont de Tassigny et al., 2008); thus, Kiss1/Dyn/NKB cell bodies in this region are unlikely to be targets for the direct action of kisspeptin. However, the kisspeptin receptor itself (as opposed to its mRNA) is concentrated in the Arc/ME region-most likely in $\mathrm{GnRH}$ terminals — based on the observation that kisspeptin can elicit $\mathrm{GnRH}$ secretion from explants of the mediobasal hypothalamus, which contains few, if any, GnRH cells bodies (Irwig et al., 2004; d'Anglemont de Tassigny et al., 2008). Thus, it seems reasonable to infer that Kiss1r appears in the ME through axonal transport, originating from sites of production in GnRH cell bodies in the medial preoptic area (Irwig et al., 2004). GnRH fibers and terminals in the ME also contain NK3 (Burke et al., 2006), suggesting that $\mathrm{GnRH}$ fibers and terminals are sites of action for both kisspeptin and NKB, but not dynorphin, because GnRH neurons apparently do not express KOR (Mitchell et al., 1997; Sannella and Petersen, 1997).

Based on what is known about kisspeptin, Dyn, and NKB signaling, we can make some predictions about their roles in this model. Assuming that NKB stimulates and Dyn inhibits Kiss1/ Dyn/NKB neurons, the recurrent collaterals constitute a potentially oscillatory feedback loop. Any spontaneous activity in the Kiss1/Dyn/NKB cells would be amplified through regenerative feedback, involving NKB/NK3 signaling. Through interconnections between Kiss1/Dyn/NKB cells, regenerative activity would propagate throughout the entire population of cells, and, as a result, a burst of kisspeptin, Dyn, and NKB would be delivered to the GnRH terminals in the ME. This would be followed by a delayed inhibition of Kiss1/Dyn/NKB cells, mediated by Dyn acting through KOR. As this subsides, the cells would become active, restarting the entire process. The kisspeptin released near $\mathrm{GnRH}$ terminals would bind to Kiss1r and initiate prolonged volleys of action potentials, and thus produce sustained $\mathrm{GnRH}$ secretion (Han et al., 2005; Pielecka-Fortuna et al., 2008; Zhang et al., 2008). To limit the release of GnRH to a discrete pulse, the activity induced by kisspeptin must somehow be extinguished. Although this could be accomplished by an unidentified inhibitory neurotransmitter, it could also occur through NKB binding to NK3 and activating a delayed inhibitory signaling pathway, as indicated in Figure 6.

If $K i s s 1 / D y n / N K B$ neurons participate in the negative feedback regulation of $\mathrm{GnRH} / \mathrm{LH}$ secretion, it would seem (at first glance) that $\mathrm{E}_{2}$ should induce Dyn expression, because Dyn is an inhibitory factor. Nevertheless, we found that $E_{2}$ suppressed lev-
Arcuate

Kiss 1/Dyn/NKB Neuron Kiss 1/Dyn/NKB Neuron

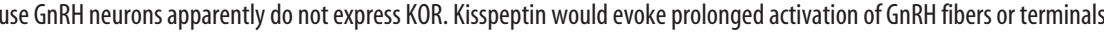
accomplish this task. Although this model is consistent with the results presented here, as well as the published observations of others, its validity requires additional critical investigation.

els of Dyn mRNA, consistent with previous results (Spampinato et al., 1995). This paradoxical observation can be readily explained by the model in Figure 6. Accordingly, the GnRH pulse generator is most active when $\mathrm{E}_{2}$ levels are low (to drive $\mathrm{GnRH}$ and LH secretion). Under these conditions, there is a demand for all three neurotransmitters (kisspeptin, Dyn, and NKB) and their receptors, as reflected by increases in the expression of their respective mRNAs. Not only was the expression of Dyn, KOR, and $N K 3$ in the Arc high when $\mathrm{E}_{2}$ levels were low, but so too was the expression of $N K B$ and Kiss1, confirming previous reports (Rance and Bruce, 1994; Dellovade and Merchenthaler, 2004; Smith et al., 2005b).

The model would also predict that exogenously administered Dyn or a Dyn agonist would suppress Kiss1/Dny/NKB neurons in the Arc, thus reducing drive to $\mathrm{GnRH}$ and $\mathrm{LH}$ secretion. In accord with this prediction, we found that the Dyn agonist U50488 inhibited LH levels, confirming previous observations in rats (Schulz et al., 1981; Kinoshita et al., 1982). We would also forecast that a permanent disruption of Dyn/KOR signaling would make the Kiss1/Dyn/NKB neurons continuously active, causing a desensitization of the kisspeptin $\rightarrow \mathrm{GnRH} \rightarrow$ LH cascade, resulting in low LH levels. Indeed, we observed reduced levels of LH in both Dyn KO and KOR KO mice, whereas Kiss1 expression remained unaltered. Furthermore, the model predicts that NKB, acting through NK3, activates Kiss1/Dyn/NKB cells in the Arc but inhibits GnRH fibers and terminals in the ME. Thus, the administration of the NKB agonist senktide would be expected to activate Kiss1/Dyn/NKB neurons but also block GnRH (and thus LH) secretion. Consistent with this expectation, senktide inhib- 
ited LH release in our mice, as it has been shown previously to do in rats (Kalra et al., 1992; Sandoval-Guzmán and Rance, 2004).

The results of this study accentuate the phenotypic differences between the two major Kiss1-expressing populations in brain located in the Arc and the AVPV. We have shown previously that, although both populations express $\mathrm{ER} \alpha$ (Smith et al., 2005b), $\mathrm{E}_{2}$ acts via an estrogen response element (ERE)-independent mechanism to inhibit Kiss1 expression in the Arc and through an EREdependent mechanism to induce Kiss1 expression in the AVPV (Gottsch et al., 2009). Here, we have shown that Kiss1 neurons in the AVPV express virtually no NKB and much less Dyn compared with those in the Arc. These phenotypic differences likely reflect the different physiological roles these neurons play in the regulation of gonadotropin secretion. In the Arc, Kiss 1 cells stimulate basal $\mathrm{GnRH} / \mathrm{LH}$ release and are negatively regulated by $\mathrm{E}_{2}$, whereas in the AVPV, they are induced by $\mathrm{E}_{2}$ and participate in generating the preovulatory $\mathrm{GnRH} / \mathrm{LH}$ surge.

In conclusion, we report that kisspeptin-expressing neurons in the Arc of the mouse coexpress Dyn and $N K B$, as well as KOR and $N K 3$, and that these neuropeptides and their receptors are targets for regulation by $\mathrm{E}_{2}$. We also demonstrate that pharmacological activation of Dyn and NKB signaling disrupts LH secretion and that animals bearing genetically targeted deletions of Dyn and KOR have compromised abilities to regulate $\mathrm{GnRH}$ secretion. We present a model whereby kisspeptin, Dyn, and NKB act autosynaptically on kisspeptin neurons in the Arc to shape the pulsatile secretion of kisspeptin and hence GnRH release. This model is consistent with the present observations and with previous reports that bursts of multiple unit activity (MUA) in the Arc of monkeys, rats, and goats are coincident with LH pulses (for review, see Nishihara et al., 1991). Nevertheless, direct testing of this model with regard to $\mathrm{GnRH} / \mathrm{LH}$ pulse generation remains to be performed in a species better suited for serial blood sampling and the measurement of MUA. Details of this model will evolve as we learn more about the specific actions of Dyn and NKB on Kiss1/Dyn/NKB neurons in the Arc and GnRH fibers and terminals in the ME.

\section{References}

Burke MC, Letts PA, Krajewski SJ, Rance NE (2006) Coexpression of dynorphin and neurokinin B immunoreactivity in the rat hypothalamus: morphologic evidence of interrelated function within the arcuate nucleus. J Comp Neurol 498:712-726.

Chavkin C, James IF, Goldstein A (1982) Dynorphin is a specific endogenous ligand of the kappa opioid receptor. Science 215:413-415.

Chowen JA, Argente J, Vician L, Clifton DK, Steiner RA (1990) Proopiomelanocortin messenger RNA in hypothalamic neurons is increased by testosterone through aromatization to estradiol. Neuroendocrinology 52:581-588.

Clarke S, Czyzyk T, Ansonoff M, Nitsche JF, Hsu MS, Nilsson L, Larsson K, Borsodi A, Toth G, Hill R, Kitchen I, Pintar JE (2002) Autoradiography of opioid and ORL1 ligands in opioid receptor triple knockout mice. Eur J Neurosci 16:1705-1712.

Cunningham MJ, Scarlett JM, Steiner RA (2002) Cloning and distribution of galanin-like peptide mRNA in the hypothalamus and pituitary of the macaque. Endocrinology 143:755-763.

d'Anglemont de Tassigny X, Fagg LA, Carlton MB, Colledge WH (2008) Kisspeptin can stimulate gonadotropin-releasing hormone ( $\mathrm{GnRH})$ release by a direct action at GnRH nerve terminals. Endocrinology 149:3926-3932.

Danzer SC, Price RO, McMullen NT, Rance NE (1999) Sex steroid modulation of neurokinin B gene expression in the arcuate nucleus of adult male rats. Brain Res Mol Brain Res 66:200-204.

Decourt C, Tillet Y, Caraty A, Franceschini I, Briant C (2008) Kisspeptin immunoreactive neurons in the equine hypothalamus Interactions with GnRH neuronal system. J Chem Neuroanat 36:131-137.

Dellovade TL, Merchenthaler I (2004) Estrogen regulation of neurokinin B gene expression in the mouse arcuate nucleus is mediated by estrogen receptor alpha. Endocrinology 145:736-742.

Dungan HM, Gottsch ML, Zeng H, Gragerov A, Bergmann JE, Vassilatis DK, Clifton DK, Steiner RA (2007) The role of kisspeptin-GPR54 signaling in the tonic regulation and surge release of gonadotropin-releasing hormone/luteinizing hormone. J Neurosci 27:12088-12095.

Foradori CD, Amstalden M, Goodman RL, Lehman MN (2006) Colocalisation of dynorphin a and neurokinin B immunoreactivity in the arcuate nucleus and median eminence of the sheep. J Neuroendocrinol 18:534-541.

Freeman ME (2005) The neuroendocrine control of the ovarian cycle of the rat. In: Physiology of reproduction (Knobil E, Neill JD, eds). New York: Raven.

Glidewell-Kenney C, Hurley LA, Pfaff L, Weiss J, Levine JE, Jameson JL (2007) Nonclassical estrogen receptor alpha signaling mediates negative feedback in the female mouse reproductive axis. Proc Natl Acad Sci U S A 104:8173-8177.

Goodman RL, Lehman MN, Smith JT, Coolen LM, de Oliveira CV, Jafarzadehshirazi MR, Pereira A, Iqbal J, Caraty A, Ciofi P, Clarke IJ (2007) Kisspeptin neurons in the arcuate nucleus of the ewe express both dynorphin A and neurokinin B. Endocrinology 148:5752-5760.

Gottsch ML, Cunningham MJ, Smith JT, Popa SM, Acohido BV, Crowley WF, Seminara S, Clifton DK, Steiner RA (2004) A role for kisspeptins in the regulation of gonadotropin secretion in the mouse. Endocrinology 145:4073-4077.

Gottsch ML, Navarro VM, Zhao Z, Glidewell-Kenney C, Weiss J, Jameson JL, Clifton DK, Levine JE, Steiner RA (2009) Regulation of Kiss1 and Dynorphin gene expression in the brain by classical and nonclassical estrogen receptor pathways. J Neurosci 29:9390-9395.

Goubillon ML, Forsdike RA, Robinson JE, Ciofi P, Caraty A, Herbison AE (2000) Identification of neurokinin B-expressing neurons as an highly estrogen-receptive, sexually dimorphic cell group in the ovine arcuate nucleus. Endocrinology 141:4218-4225.

Han SK, Gottsch ML, Lee KJ, Popa SM, Smith JT, Jakawich SK, Clifton DK, Steiner RA, Herbison AE (2005) Activation of gonadotropin-releasing hormone neurons by kisspeptin as a neuroendocrine switch for the onset of puberty. J Neurosci 25:11349-11356.

Irwig MS, Fraley GS, Smith JT, Acohido BV, Popa SM, Cunningham MJ, Gottsch ML, Clifton DK, Steiner RA (2004) Kisspeptin activation of gonadotropin releasing hormone neurons and regulation of KiSS-1 mRNA in the male rat. Neuroendocrinology 80:264-272.

Kalra PS, Sahu A, Bonavera JJ, Kalra SP (1992) Diverse effects of tachykinins on luteinizing hormone release in male rats: mechanism of action. Endocrinology 131:1195-1201.

Keen KL, Wegner FH, Bloom SR, Ghatei MA, Terasawa E (2008) An increase in kisspeptin-54 release occurs with the pubertal increase in luteinizing hormone-releasing hormone-1 release in the stalk-median eminence of female rhesus monkeys in vivo. Endocrinology 149:4151-4157.

Kinoshita F, Nakai Y, Katakami H, Imura H (1982) Suppressive effect of dynorphin-(1-13) on luteinizing hormone release in conscious castrated rats. Life Sci 30:1915-1919.

Krajewski SJ, Anderson MJ, Iles-Shih L, Chen KJ, Urbanski HF, Rance NE (2005) Morphologic evidence that neurokinin B modulates gonadotropinreleasing hormone secretion via neurokinin 3 receptors in the rat median eminence. J Comp Neurol 489:372-386.

Lubahn DB, Moyer JS, Golding TS, Couse JF, Korach KS, Smithies O (1993) Alteration of reproductive function but not prenatal sexual development after insertional disruption of the mouse estrogen receptor gene. Proc Natl Acad Sci U S A 90:11162-11166.

McLaughlin JP, Marton-Popovici M, Chavkin C (2003) $\kappa$ opioid receptor antagonism and prodynorphin gene disruption block stress-induced behavioral responses. J Neurosci 23:5674-5683.

Miller GM, Silverman AJ, Rogers MC, Gibson MJ (1995) Neuromodulation of transplanted gonadotropin-releasing hormone neurons in male and female hypogonadal mice with preoptic area brain grafts. Biol Reprod 52:572-583.

Mitchell V, Prevot V, Jennes L, Aubert JP, Croix D, Beauvillain JC (1997) Presence of mu and kappa opioid receptor mRNAs in galanin but not in GnRH neurons in the female rat. Neuroreport 8:3167-3172.

Nishihara M, Hiruma H, Kimura F (1991) Interactions between the noradrenergic and opioid peptidergic systems in controlling the electrical activ- 
ity of luteinizing hormone-releasing hormone pulse generator in ovariectomized rats. Neuroendocrinology 54:321-326.

Paxinos G, Franklin K (2001) The mouse brain in stereotaxic coordinates. San Diego: Academic.

Pielecka-Fortuna J, Chu Z, Moenter SM (2008) Kisspeptin acts directly and indirectly to increase gonadotropin-releasing hormone neuron activity and its effects are modulated by estradiol. Endocrinology 149:1979-1986.

Pillon D, Caraty A, Fabre-Nys C, Bruneau G (2003) Short-term effect of oestradiol on neurokinin B mRNA expression in the infundibular nucleus of ewes. J Neuroendocrinol 15:749-753.

Popa SM, Clifton DK, Steiner RA (2008) The role of kisspeptins and GPR54 in the neuroendocrine regulation of reproduction. Annu Rev Physiol 70:213-238.

Ramaswamy S, Guerriero KA, Gibbs RB, Plant TM (2008) Structural interactions between kisspeptin and GnRH neurons in the mediobasal hypothalamus of the male rhesus monkey (Macaca mulatta) as revealed by double immunofluorescence and confocal microscopy. Endocrinology 149:4387-4395.

Rance NE, Bruce TR (1994) Neurokinin B gene expression is increased in the arcuate nucleus of ovariectomized rats. Neuroendocrinology 60:337-345.

Sandoval-Guzmán T, Rance NE (2004) Central injection of senktide, an NK3 receptor agonist, or neuropeptide $\mathrm{Y}$ inhibits $\mathrm{LH}$ secretion and induces different patterns of Fos expression in the rat hypothalamus. Brain Res 1026:307-312.

Sannella MI, Petersen SL (1997) Dual label in situ hybridization studies provide evidence that luteinizing hormone-releasing hormone neurons do not synthesize messenger ribonucleic acid for mu, kappa, or delta opiate receptors. Endocrinology 138:1667-1672.

Schulz R, Wilhelm A, Pirke KM, Gramsch C, Herz A (1981) Beta-endorphin and dynorphin control serum luteinizing hormone level in immature female rats. Nature 294:757-759.

Smith JT, Dungan HM, Stoll EA, Gottsch ML, Braun RE, Eacker SM, Clifton DK, Steiner RA (2005a) Differential regulation of KiSS-1 mRNA expression by sex steroids in the brain of the male mouse. Endocrinology 146:2976-2984.

Smith JT, Cunningham MJ, Rissman EF, Clifton DK, Steiner RA (2005b) Regulation of Kiss1 gene expression in the brain of the female mouse. Endocrinology 146:3686-3692.

Spampinato S, Canossa M, Campana G, Carboni L, Bachetti T (1995) Estrogen regulation of prodynorphin gene expression in the rat adenohypophysis: effect of the antiestrogen tamoxifen. Endocrinology 136: 1589-1594.

Topaloglu AK, Reimann F, Guclu M, Yalin AS, Kotan LD, Porter KM, Serin A, Mungan NO, Cook JR, Ozbek MN, Imamoglu S, Akalin NS, Yuksel B, O'Rahilly S, Semple RK (2009) TAC3 and TACR3 mutations in familial hypogonadotropic hypogonadism reveal a key role for Neurokinin B in the central control of reproduction. Nat Genet 41:354-358.

Zhang C, Roepke TA, Kelly MJ, Rønnekleiv OK (2008) Kisspeptin depolarizes gonadotropin-releasing hormone neurons through activation of TRPC-like cationic channels. J Neurosci 28:4423-4434. 